\title{
Alexandre Herculano's Romantic Hero In Eurico, o Presbítero: The Unbridled Search For the Absolute
}

\author{
T. Mendes and L. Cardoso
}

\begin{abstract}
Alexandre Herculano (1810 - 1877) is considered the introducer of the historical novel in Portugal and one of the greatest writers of the romantic literary movement in Portugal. Based on a concrete historical background, his work Eurico, O Presbítero, reflects the priest's social condition and the imposition of monastic celibacy. The hero emerges in a dilemma, deeply divided between an overwhelming passion and ethical and religious imperatives. He is the example of the romantic, troubled and divided hero, lonely, unhappy and misunderstood, in perpetual demand for himself, as we will try to demonstrate in this paper.
\end{abstract}

Keywords-Romantic hero, historic novel, Alexandre Herculano

\section{INTRODUCTION}

In the historic novel Eurico, O Presbitero, published in 1844 , the problematic hero appears in a situation of antagonism with the degraded structures of the Visigothic monarchy, on the eve of the Arab invasion, in the 711th year, in Iberian Peninsula. Profoundly disturbed with this reality, Eurico is the emblematic figure who axiologically opposes himself to a corrupt society, undermined by betrayals and excessive ambitions, originating absence of values and death. He adopts characteristics of the epic hero, moved by virtue, honor, religious values and the love of the motherland, in an unbridled search for the Absolute. That's why he's alone. And so it has to die from the diegetic point of view. In fact, in order to have discursive coherence, the hero can not be incorporated by a decrepit society which he contested $a b$ initio, a society from which he categorically moves away.

His insertion in the religious life is therefore motivated above all by love and existential failure and not by simple devotion. Due to this love disappointment, the hero is drawn into the solitude of Calpe where he lives a life of meditation until the inevitable metamorphosis that drives him to action.

This life of introspection makes him wander through the most hidden places, causing strangeness to the people of Carteia. However, after the first suspicions of the indigenous population, Eurico acquires a mythical status by being recognized as "inspired by God" (29), almost a prophet, because, besides

T. Mendes is with the Polytechnic Institute of Portalegre (Portugal) with the Dep. of Languages and Communication.

L. Cardoso is with the Polytechnic Institute of Portalegre (Portugal) with the Department of Languages and Communication being a priest, he is also (perhaps even for this very reason) the poet, with an unusual sensitivity, which, among other things, characterizes the romantic hero.

His mythical and legendary side is imposed when, visionarily, he foresees the tragic end of the beloved homeland, and this omen will trigger commitment and decision-making ("Land in which I was born, if your day of dying is [an inevitability), I will die with you "). The warrior, with a mysterious and unique aspect (Black Knight), with a prodigious energy that allows him to perform extraordinary feats, is, presumably, the last hero of his strain, being his meteoric action described through a strongly evaluative discourse. This image is also built by anonymity and his marginal superiority that will enable him to engage more actively in the struggle for the motherland. However, this hero will humanize himself by saving Hermengarda, the woman he loves, from the arms of Abdulaziz.

But the truth is that Eurico, as priest, warrior and lover, will not have a diegetic hypothesis of survival because of his sacrilege, even if it is only committed in thought. Therefore, this demigod, humanized by contradictory feelings, must immolate himself through the desperate internal and external struggle and only in this voluntary suicidal act will there be possibility of reaching the religious absolute.

Thus, we are in the presence of an authentic romantic hero, personalized in the priest-poet who carries within himself the warrior, made mythical by his demolishing action, and the unfortunate lover, who gains a tragic dimension for the impossibility of this love, self-imposed by ethical imperatives. Therefore, he is "a true romantic hero, because his relationship with the world and with others translates into the conflict between the quest for absolute, the struggle of the ideals of love, religion and homeland, and the systematic denial of these ideals by reality and by men. It is therefore driven to inevitable destruction "(Reis, 1994,p. 54).

$\mathrm{He}$ is the main character invaded by an amalgamation of affections (by a woman, his religion and his homeland) and his quest for absolute reflects the modern hero's need to follow his rules and ethical imperatives regardless of pragmatic effects and possibility or impossibility of achieving their intimate goals. Not adapting himself to the conventional rules, to everything that is socially imposed, Eurico establishes a border between the interior and the exterior by the creation of an axiologically differentiated universe (Lotman, 1990, p. 134); so he remains with his hidden identity and he lives self-absorbed, tied to the memories of a sad past that he will not be able to recover. Curiously, the hero is aware of this impossibility and the desperate struggle against the "others" (the Arabs, but especially the Gothic traitors). His action therefore consists to 
defend the patriarchal ideals that guide him, which must be understood as the outpouring of anguish and frustration of a life pursued by the fatum and, ultimately, as a gigantic struggle with itself from which there is no possibility of return.

Hence, he is the lonely hero, longing to expand his pain in the vastness of the wide open spaces. His disbelief causes him to fall into a state of deep disillusionment which is expressed outwardly by the adoption of a contemplative and wandering life. "I was drawn to the wilderness by an intimate feeling, the feeling of having awakened, still alive, from this feverish dream called life, and that today nobody wakes up, only after dying" (36). In this reference to solitude, Eurico evidences his inner feeling by associating it with the painful awakening of the poet. It is then that for him (poet) there is only one real life - the intimate one; only an intelligible language - that of the roaring of the sea and the roar of the winds; only a coexistence not wrought by perfidy - that of solitude "(37). Thus, through anaphoric parallelism and rhetorical repetition, Eurico, sublimating the introspective existence of the poet (and implicitly his), makes the apology of interiorization, felt as the only authentic life; of the pursuit of an immaculate and magnificent (and therefore comforting) nature; and the taste of isolation, as the only coexistence devoid of falsehood.

Eurico is thus the solitary hero, unhappy and misunderstood, in perpetual demand for himself, reviving the ghosts of the past in tormented and frustrating memories of eternally delayed loving happiness; the hero unhappy with the perfidy and the ignominy that devour the human race and in particular the Visigothic society; the hero who is not adapted to his time and adopts, therefore, a position of marginality that the reader is led to consider proper of a genius and a demigod; the hero, at last, unable to solve the dilemma he is in, who wanders "crazy over the mountains, howling like the hungry wolf and trying to shatter the cliffs with his hands, from (...) blood "(47).

Wandering fantastically through the bay of Carteia or the mountains of Calpe, Eurico leads a life of renunciation and disenchantment, allowing himself to be cradled in his thoughts. This life, wandering through the vast and natural (and therefore impolitic) spaces, can not be understood by anyone who is governed by stereotyped social norms and is inevitably framed by petty limits, that is, the "rude people of Carteia" (26).

And if the psychic vigor spoken of by Carlos Reis (1997, p. 232 ) is what makes the romantic hero "... an entity endowed with a dynamism oriented towards overcoming ..." then one understands that "Such dynamism (the) eagerness of absolute, generating a superenergy that is also the root of confrontations between the romantic hero and the common mortal, insensitive to the ideas he pursues (ibidem).

The physical and geographical space that serves as a backdrop to the whole romanesque intrigue deserved, on the part of the narrator, a very special attention. In fact, strategic spaces such as Carteia, Calpe, Covadonga, Chrysus and Sália are described in detail and integrated into even wider spaces such as Spain and Asturias. As dramatic intensity increases, these spaces tend to be reduced to allow the inevitable encounter of Eurico and Hermengarda in the restricted space of the cave of Covadonga, where the terrible revelation of the hero and the tragic climax of the intrigue take place.

It is in this proliferation of spaces that the hero wanders, having a noticeable incidence in the large, natural and immaculate spaces, grandiose and sublime that meet the needs of immensity and infinite on the part of the hero. Thus, Eurico is strongly attracted to the sea. It is in the sea that he lives a situation of relative tranquility when it rambles of boat around Green Island. Once again, he is physically and spiritually distant from others. It is therefore this sea that seduces and witnesses the wandering of an anguished and dilemmatic being by the bay of Carteia or by the cliffs and mountainous rocks of Calpe.

Far from everything and everyone, Eurico finds himself in a geographically peripheral situation in the south of Spain, in the village of Carteia. This location will have a symbolic value since it corresponds to the period of immobilism provoked by the confused and chaotic spiritual characteristics of the hero (characteristic of all reflexive activity). It is understandable, therefore, that the movements are circular since Eurico delves in search of his spiritual path.

However, when he feels the call of the fatherland, "The only eternal affection that perhaps remains to this heart purified by the fire of misery ..." (56), the hero moves from immobility to action, transforming himself into the epic hero and mysterious that sows panic in the field of the enemy. This commitment corresponds to a change of movements that circulate from straight to straight because they have found a goal to be achieved. At the same time, the hero leaves a peripheral and isolated area and heads north, Asturias, where the center of the warrior action is located. It is there that Eurico will again face the "others" from whom he had distanced himself by various incompatibilities. It is there that he will show his heroism fighting alone against the world, in punctual and enigmatic apparitions but truly devastating. It is there, however, that, after the impossibility of reaching the absolute on a personal and collective level, the hero will immolate himself in the sacrifice of the struggle for the motherland (and, metonymically, by himself). This is, in fact, the foreseeable end of this romantic hero, in permanent conflict with himself and with others. In fact, he is the real romantic hero "for his primary confrontation is with himself rather than with society." (Furst, 1979, p. 45).

\section{REFERENCES}

[1] Furst, Lilian (1979). The Romantic Hero, or is he na Anti-hero?. The Contours of European Romanticism. London: McMillan. https://doi.org/10.1007/978-1-349-04397-2

[2] Herculano, Alexandre (1984). Eurico, o Presbitero. Mem Martins: Publicações Europa-América.

[3] Lotman, Yuri (1990). The notion of boundary. Universe of the Mind. A Semiotic Theory of Culture. Indiana UP.

[4] Reis, Carlos (1994). in Martins, M. Alexandre Herculano - «Eurico, o Presbítero». Mem Martins: Publicações Europa-América.

[5] Reis, Carlos (1997). Herói. Buescu, Helena. (Coord.). Dicionário do Romantismo Português. Lisboa: Editorial Caminho. 


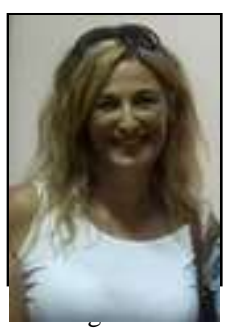

T. Mendes was born in Portalegre (Portugal) in 1968. After concluding the degree in Portuguese and French Teaching at the Evora University in 1991, she concluded a Master in Comparative Literature at Lisboa University in 2001. In 2009 she concluded her $\mathrm{PhD}$ in Literary Studies at Lisboa University (Portugal)

After teaching for four years in secondary schools, she began teaching at the Polytechnic Institute of She has been Coordinator of the Basic Education Degree at this Institute since 2013, and Institutional Coordinator of the Languages Center of the Polytechnic Institute of Portalegre since 2015. Her main interests in teaching and investigation include Science and Communication Languages, Comparative Literature, Children's Literature and Education. In 2015, she published the book Vozes e Silêncio: a Poética do (Des)encontro na Literatura para Jovens. España: Editora Bubok Publishing.

Prof. Dr. Mendes was the institutional coordinator of the Portuguese National Education Program and she has published several papers in national and international journals with peer review. She is a researcher member of the Comparative Studies Center of the Lisboa University and the Interdisciplinary Research and Innovation Coordination of the Polytechnic Institute.

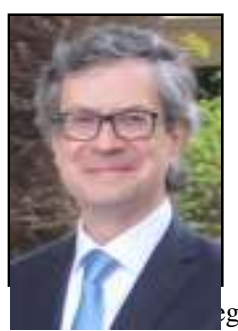

L. Cardoso was born in Viseu (Portugal) in 1969. After concluding the Humanities degree at the Catholic University in 1991, he concluded a Master in Classic Literatures at Coimbra University, in 1996. In 2007 he concluded his PhD in Modern Languages and Literatures at Coimbra University (Portugal).

After teaching for four years in secondary schools, he began teaching at the Polytechnic Institute of Viseu in 1995 until 2008, when he moved to the Polytechnic gre as Adjunct Professor. He was elected Dean of the School of Education and Social Sciences in 2010 until february 2018, completing the two mandates permitted by law. Since 2015 until May, 2018, he was also President of ARIPESE - the Association for Reflexion and Intervention in Higher Schools Polytics. Main interests in teaching and investigation include Science and Communication Languages, Literature and Cinema, and Management of Higher Education Universities. In 2016, he published Literature and Cinema: the look of Janus. Vergílio Ferreira and the space of the unspeakable.

Prof. Dr. Cardoso was the national coordinator for the Bologna Process in Polytechnics in Media and Communication Sciences. He is a member of several international organizations concerning Education, Communication, Comparative Literature, Narratology, Film Studies and Higher Education Management and reviewer of several international journals. 